\title{
骨材除去後の廃コンクリート微粉末からの素材分離 MATERIAL SEPARATION OF WASTE CONCRETE FINE POWDER
}

\author{
竹本 喜 昭*, 橋田 浩**, 黒田泰弘***, 榎本尚 也**** \\ 赤津 隆*****, 田中享二****** \\ Yoshiaki TAKEMOTO, Hiroshi HASHIDA, Yasuhiro KURODA, \\ Naoya ENOMOTO, Takashi AKATSU and Kyoji TANAKA
}

\begin{abstract}
The measure which manufactures high quality recycled aggregate from the concrete block produced at the time of building demolition is taken. In this process, the waste concrete fine powder (WCFP) is produced in large quantities. However WCFP does not have the available usage. In this study, we first made the process which divides WCFP into $\mathrm{SiO}_{2}$ and $\mathrm{CaCO}_{3}$. Next, from a viewpoint of processing efficiency, we optimized acid concentration, the balance of WCFP and dissolution time.
\end{abstract}

Keywords : Waste concrete fine powder, Material separation, CO2,Calcium carbonate, Material balance 廃コンクリート微粉末、素材分離、二酸化炭素、炭酸カルシウム、マテリアルバランス

\section{1.はじめに}

地球温暖化は、ここ近年になって我々の身近な問題として取り上 げられるようになってきており、二酸化炭素の排出量削減や資源の リサイクルに対しての関心が高まっている。建築物についても高度 成長期に建設された構造物が 30 年から 40 年経過し、これらの更新 によって発生するコンクリート塊の急激な増大が見込まれている。 この問題に対しては、これまでも例えば解体コンクリートからセメ ント水和物と骨材を分離して、再生骨材を製造する等いくつかの取 り組みがなされている。しかし現状と同程度のコンクリートを作る ために、再生骨材も高品質のものが望まれる傾向にあり、そのため 骨材に付着しているセメント水和物をできるだけきれいに除去され ることが求められている。そうすると当然骨材表面も擦り落とされ るため、さらに廃コンクリート微粉末も増え、結果として現状では、 元のコンクリートのおおよそ $40 \%$ もの量が微粉末として残されてい る ${ }^{1)}$ 。これの用途として、建材の原料に混入あるいは地盤改良材と して利用する方法が提案されているが、汎用技術としては不十分と 思われる。そこで、この廃コンクリート微粉末を一般工業に使用可 能な原料水準までの素材に分離できれば、その処理に困窮している 微粉末の用途を格段に広めることが可能となる。これを背景に本研 究は、微粉末が多量のセメント水和物を含むため強いアルカリ性で
あることを踏まえ、これを酸によって溶解させるプロセスを基本と して、最終的に工業用途に使用できる水準の炭酸カルシウムとケイ 酸を製造する技術の確立を目標とするが、特に本報告ではその第一 段階として、骨材除去後の廃コンクリート微粉末の素材分離方法を 検討し、適切な分離のための条件を明らかにすることを目的とする。 既往の研究として、 $\mathrm{CO}_{2}$ を炭酸塩として固定するミネラリゼーシ ヨン技術の研究開発が検討されており、廃コンクリートがその一原 料として検討されている。その方法の一つに、廃コンクリート微粉 末を高圧炭酸水で処理し、炭酸カルシウムを析出させる方法 ${ }^{2)}$ が提 案されているが、気密反応槽を用いるため、大量の処理を必要とす る廃コンクリート微粉末には向いていないと思われる。また、他の 方法としては、塩化アンモニウム水溶液を加温することでアンモニ アを気化して酸性とし、カルシウムを含む廃棄粉末を投入・溶解し てイオン化し、溶液を炭酸化することによって炭酸カルシウムを析 出する方法である ${ }^{3)}$ 。この方法は、溶液を繰返し使用することがで きるとされているが、溶液の酸性が低いため、不純物が多く、カル シウム分が少ない廃コンクリート微粉末の処理には適していない。

そのため本研究では新しい手法として、多量の廃コンクリート微 粉末を、一旦、酸によって分解・処理を行うことによって、含有し ているカルシウムやケイ素などの他、酸に溶解しない骨材の屑など

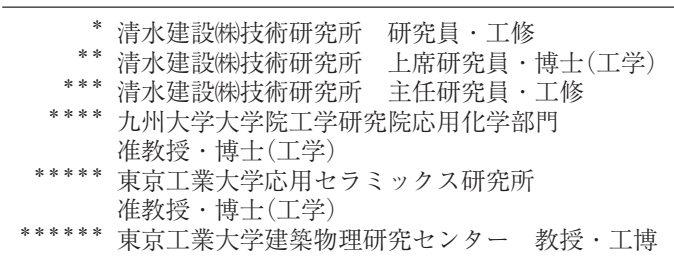

Research Engineer, Technology Development Div., Shimizu Corporation, M. Eng. Chief Research Engineer, Institute of Technology, Shimizu Corporation, Dr. Eng. Senior Research Engineer, Institute of Technology, Shimizu Corporation, M. Eng. Assoc. Prof., Department of Applied Chemistry, Faculty of Engineering, Kyushu Univ., Dr. Eng.

Assoc. Prof., Materials and Structures Laboratory, Tokyo Institute of Technology, Dr. Eng. Prof., Structural Engineering Research Center, Tokyo Institute of Technology, Dr. Eng. 
の素材をそれぞれに分離する検討を行った。検討は以下のとおりに 進めた。

（1）素材分離のプロセス検討 : 廃コンクリート微粉末から、素材を 分離するプロセスを構築するための検討を行った。

（2）プロセスの最適条件検討 : 構築したプロセスの最も効率よい条 件について検討した。

（3）マテリアルバランス検討：プロセスの最適条件によって得られ た分離素材のマテリアルバランス（本論文では、分離素材の合計に 対する各分離素材の割合とする）を比較し、さらに改善するよう検 討を行った。

\section{2. 素材分離プロセス検討}

\section{1 試験計画}

\subsection{1 試験試料}

試験に用いたのは廃コンクリート微粉末と、比較用のためにセメ ントペーストを微粉砕したセメント微粉末である。廃コンクリート 微粉末とは、実際の解体現場において重機によって大きな塊に砕い た後に、破砕機によって粒径 $40 \mathrm{~mm}$ 以下とした廃コンクリートを $300^{\circ} \mathrm{C}$ に加熱し、すりもみ機械を用いて粗・細骨材を分離・回収した 際に副産したセメント水和物の粉末である。試験体として用いたの は、この廃コンクリート微粉末を $0.15 \mathrm{~mm}$ の穊いに通したものである。 比較用のセメント微粉末は、W/C $=40 \%$ のメントペーストを $\phi 5 \mathrm{~cm}$ $\times 10 \mathrm{~cm}$ に成形し、 $50^{\circ} \mathrm{C}$ 水中養生を 3 ケ月間行った後に粉砕・乾燥し、 $0.15 \mathrm{~mm}$ の節いを通したものである。表 1 には、電子線マイクロ分析 器（以下、EPMA）によって分析した廃コンクリート微粉末と、比較 としてポルトランドセメントの成分内訳を示す ${ }^{1)}$ 。廃コンクリート 微粉末は、骨材表面に付着したセメント水和物を擦り落とすことに より排出されるため、骨材の削り屑も多く混入する。したがって、 廃コンクリート微粉末はケイ素分がポルトランドセメントよりも多 くなり、逆にカルシウム成分が少ないのが特徵である。

表 1 ポルトランドセメントと廃コンクリート微粉末の内訳（mass％)

\begin{tabular}{c|c|c|c|c|c|c|c|c}
\hline 種類 & $\mathrm{Si}_{2}$ & $\mathrm{Al}_{203}$ & $\mathrm{Fe}_{203}$ & $\mathrm{Ca} 0$ & $\mathrm{Mg} 0$ & $\mathrm{S0} 3$ & $\mathrm{C} 1$ & $\mathrm{Na} 20 \mathrm{eq}$ \\
\hline $\begin{array}{c}\text { ポ トランド } \\
\text { セメント }\end{array}$ & 21.2 & 5.2 & 2.8 & 64.2 & 1.5 & 2.0 & 0.005 & 0.63 \\
\hline $\begin{array}{c}\text { 廃コンクリート } \\
\text { 微粉末 }\end{array}$ & 50.8 & 10.1 & 2.7 & 23.5 & 1.3 & 0.8 & 0.015 & 1.94 \\
\hline
\end{tabular}

\subsection{2 試験方法}

廃コンクリート微粉末およびセメント微粉末を酸に溶解させ、処 理の過程でそれぞれの成分を分離し、最終的にはカルシウムに二酸 化炭素を固定化させ、炭酸カルシウムを析出させる実験を行った。 手順は以下のとおりである。

\section{(1) 微粉末の溶解}

廃コンクリート微粉末およびセメント微粉末それぞれ $2.5 \mathrm{~g}$ を、濃 度 $2 \mathrm{~N}$ の塩酸 $100 \mathrm{~m} 1$ に少しずつ投入し、十分に溶解させるために約 18 時間攪拌した。

（2）アンモニア水による中和

十分に攪汼した塩酸溶解液をろ過し、溶解しない不溶残分を分離 した。得られた溶液に市販のアンモニア水 $(28 \%$ 濃度) を攪拌しな
がら少しずつ滴下して、pHメーターで確認しながら $\mathrm{pH}$ を徐々に上昇 させ、 $\mathrm{pH} 7$ まで滴下を行った。アンモニア水を滴下しながら溶液の変 化を観察し、析出物が発生した場合は分離した。ここで得られた不 溶残分や析出物は、付着している塩酸溶解液を洗い流寸ため純水で 洗浄し、 $110^{\circ} \mathrm{C}$ に設定したオーブンで乾燥させた。

（3）溶液の炭酸化

アンモニア水滴下後にろ過・分離した中和液に $\mathrm{C}_{2}$ を吹込み、十 分に炭酸化した。得られた析出物は遠心分離により溶液と分離し、 純水で洗浄した後に $110^{\circ} \mathrm{C}$ 設定したオーブンで乾燥させた。

\section{2 試験結果}

\section{2.1 微粉末の溶解}

（1）不溶残分（沈殿物）

セメント微粉末と廃コンクリート微粉末は、発熱しながらガスを 発生して塩酸に溶解した。このガスを捕捉し、検知管で簡易的に調 べたところ $\mathrm{CO}_{2}$ と微量の $\mathrm{H}_{2}$ であった。セメント微粉末の不溶残分は 微量であり、EPMA とX線回折で成分分析したところ、Si02 が $65.4 \%$ と最も多く、石英とカルシウム水和物であった。廃コンクリート微 粉末は塩酸に溶解しない不溶残分 (沈殿物) が多く、これを純水で 洗浄・乾燥した後に EPMA とX 線回折で成分を調べたところ、 SiO2 が $67.0 \%$ と最も多く、石英、長石類および白雲母などであった。これ らは、骨材を由来とする鉱物と考えられる。不溶残分を分離した塩 酸溶解液は、セメント微粉末と廃コンクリート微粉末のどちらも鮮 やかな黄色であった。表 2 に塩酸溶解における状況を比較して示寸。

表 2 微粉末の溶解における状況の比較

\begin{tabular}{|c|c|c|c|}
\hline 種類 & 溶解時の状況 & 塩酸溶解液 & 不溶残分の内訳 \\
\hline セメント微粉末 & \multirow{2}{*}{$\begin{array}{l}\cdot \mathrm{CO}_{2} \text { と微量の } \mathrm{H}_{2} \text { 発生 } \\
\cdot \text { 発熱 }\end{array}$} & \multirow{2}{*}{$\begin{array}{l}\text { 鮮やかな } \\
\text { 黄色 }\end{array}$} & 石英、カルシウム水和物 \\
\hline $\begin{array}{l}\text { 廃コンクリート } \\
\text { 微粉末 }\end{array}$ & & & 石英、長石類、白雲卡 \\
\hline
\end{tabular}

（2）塩酸溶解液とゲルの分離

この黄色の塩酸溶解液は室内に放置しておくと、時間の経過と共 にゆっくりとゲル化する性質を持つことが確認された。このゲル化 した塩酸溶解液を遠心分離し、純水で十分に洗浄すると白色半透明 のゲル状物質が得られた。これを $110^{\circ} \mathrm{C} に$ 設定したオーブンにより乾 燥させ EPMA によって成分を分析したところ、約 $96 \%$ が $\mathrm{SiO}_{2}$ であっ た。これは、塩酸によって溶解したケイ素分が、酸性溶解液中でゲ ル化したと考えられる。

ここで、塩酸に廃コンクリート微粉末の重量を変えて溶解し、不 溶残分を分離した塩酸溶解液を蓋付きの試験管に密封した状態とし、 養生温度を変えてゲル化速度を調べた。結果を表 3 に示す。ゲル化 は濃度と温度に依存する傾向が見られたが、 $100^{\circ} \mathrm{C} の$ 加熱状態でも約 12 時間〜3 日かかり、ゲル化速度は遅いことが分かった。

表 3 塩酸溶解液のゲル化時間

\begin{tabular}{c|c|c|c|c|c}
\hline \multirow{2}{*}{$\begin{array}{c}\text { 塩酸 } 100 \mathrm{~m} 1 \text { に対 } \\
\text { する微粉末重量 }\end{array}$} & \multicolumn{5}{|c}{ 養生温度・ゲル化時間 } \\
\cline { 2 - 6 } & $20^{\circ} \mathrm{C}$ & $40^{\circ} \mathrm{C}$ & $60^{\circ} \mathrm{C}$ & $80^{\circ} \mathrm{C}$ & $100^{\circ} \mathrm{C}$ \\
\hline $2.5 \mathrm{~g}$ & 約 30 日 & 約 25 日 & 4 日 & 4 日 & 3 日 \\
\hline $5.0 \mathrm{~g}$ & 約 30 日 & 6 日 & 4 日 & 2 日 & 約 18 時間 \\
\hline $10.0 \mathrm{~g}$ & 6 日 & 4 日 & 3 日 & 1 日 & 約 12 時間 \\
\hline
\end{tabular}




\section{2.2 ゲル分離後の塩酸溶解液のアンモニア水による中和とそれ} により生じたゲルの分離

ゲル化したケイ酸を分離した後の塩酸溶解液は、透明で鮮やかな 黄色であった。この溶液にアンモニア水を徐々に滴下していくと、 pH2 あたりから全体が褐色のゲル状となり、pH3 あたりではやや白く なりながらさらにゲル化が進み、急激に流動性を失った。この赤褐 色ゲルを遠心分離機で分離し、純水で洗浄・乾燥して成分を分析し た結果を表 4 に示す。この赤褐色ゲルは、鉄分とアルミニウムが主 成分であった。その他の塩素、カルシウムは、鉄とアルミニウムが ゲル化した際に塩酸溶解液を取り込んだものであり、純水による洗 浄で除去できなかったと考えられる。

表 4 赤褐色ゲルの成分内訳 (mass \%)

\begin{tabular}{c|c|c|c|c|c|c|c}
\hline $\mathrm{A}_{2} \mathrm{O}_{3}$ & $\mathrm{Fe}_{20} \mathrm{O}_{3}$ & $\mathrm{Cl}_{20} \%$ & $\mathrm{Ca} 0$ & $\mathrm{S0}_{3}$ & $\mathrm{Zn0}$ & $\mathrm{SiO}_{2}$ & $\mathrm{P} 2 \mathrm{O}_{5}$ \\
\hline 29.3 & 22.8 & 18.4 & 12.3 & 7.6 & 5.1 & 2.1 & 1.9 \\
\hline
\end{tabular}

※酸化物換算値

鉄やアルミニウムイオンは、溶液の $\mathrm{pH}$ によって溶解度が変化する 性質を持っている。図 1 に示すように、3 価の鉄イオン $\left(\mathrm{Fe}^{3+}\right)$ は $\mathrm{pH} 2$ あたりから赤褐色の $\mathrm{Fe}(\mathrm{OH}) 3$ として、3 価のアルミニウムイオン

$\left(\mathrm{Al}^{3+}\right)$ は、 $\mathrm{pH} 3$ あたりから白色の $\mathrm{Al}(\mathrm{OH})_{3}$ としてゲル状沈殿となる 性質がある。鉄とアルミニウムはセメントに由来する成分であり、 強酸に溶解した後にアンモニア水の中和によって $\mathrm{pH}$ が上昇すること によってゲル化したと考えられる。

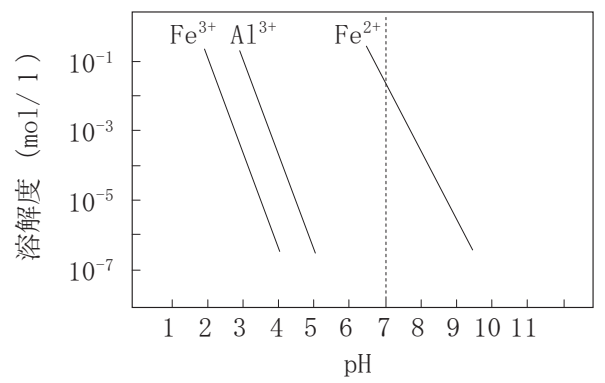

図 1 鉄、アルミニウムイオンの溶解度 ${ }^{4)}$

\section{2.3 ゲル分離後のアンモニア中和液の炭酸化}

赤褐色ゲルを分離した後のアンモニア水による中和液は、無色透 明となった。これに $\mathrm{CO}_{2}$ を吹込んで炭酸化すると、中和液が徐々に 白濁した。中和液を十分に炭酸化させ、得られた白色析出物を遠心 分離し、十分に洗浄・乾燥させた。この白色析出物を EPMAによって 分析したところ、表 5 に示すようにほぼ純粋な炭酸カルシウム（以 下、 $\mathrm{CaCO} 3)$ であった。

表 5 白色析出物の成分内訳 (mass\%)

\begin{tabular}{c|c|c|c|c}
\hline $\mathrm{Ca} 0$ & $\mathrm{Cu} 0$ & $\mathrm{SO}_{3}$ & $\mathrm{C}_{2} 0^{*}$ & $\mathrm{P}_{205}$ \\
\hline 89.9 & 3.0 & 2.7 & 2.6 & 1.8 \\
\hline
\end{tabular}

\section{※酸化物換算值}

$\mathrm{CO}_{2}$ 吹込みによってアンモニア水による中和液を炭酸化するには 時間がかかり、また、炭酸化の程度が判断しにくい。そこで、アン モニア中和液を短時間で、より確実に炭酸化させるため、 $\mathrm{C}_{2}$ 吹込み に代えて炭酸アンモニウム水溶液を滴下した。 $\mathrm{C} 02$ 吹込みで得られた $\mathrm{CaCO}_{3}$ と、炭酸アンモニウム滴下で得られた $\mathrm{CaCO}_{3}$ を比較して写真 1
に示す。

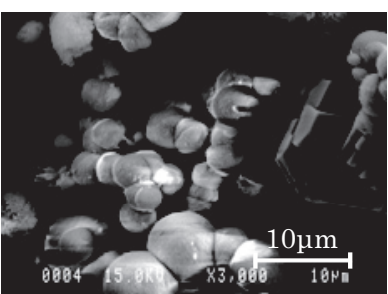

(1) $\mathrm{CO}_{2}$ 吹込夕

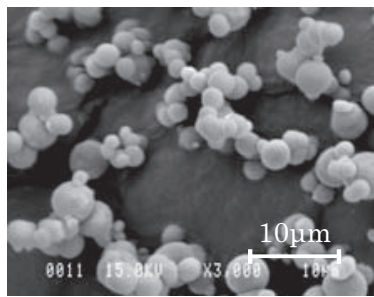

(2) 炭酸アンモニウム滴下
写真 1 析出した $\mathrm{CaCO}_{3}$ の結晶

$\mathrm{CO}_{2}$ 吹込みで得られた $\mathrm{CaCO}_{3}$ は、 $\mathrm{X}$ 線回折で分析すると図 2 に示寸 ようにカルサイトとバテライトであった。炭酸アンモニウム滴下で 得られた $\mathrm{CaCO}_{3}$ を同様にX線回折で分析したところ、ほとんどがバ テライトであり、約 2 $4 \mu \mathrm{m}$ 程度で揃っていた。 $\mathrm{CaCO}_{3}$ は、アンモニ アの存在下ではバテライトとなりやすいとされている ${ }^{5)}$ 。また、 $\mathrm{CaCO}_{3}$ には、カルサイト、アラゴナイト、バテライトの 3 つの結晶構造が あり、カルサイトが最も安定相で、バテライトは不安定相である。 したがって、写真 1 (1) に示す $\mathrm{CaCO}_{3}$ は、 $\mathrm{CO}_{2}$ 吹き込みの影響により、 バテライトから安定相のカルサイトに一部変化したと考えられる。

$\mathrm{CaCO}_{3}$ を分離した後の溶液は、無色透明であった。これは、塩化ア ンモニウムの水溶液である。

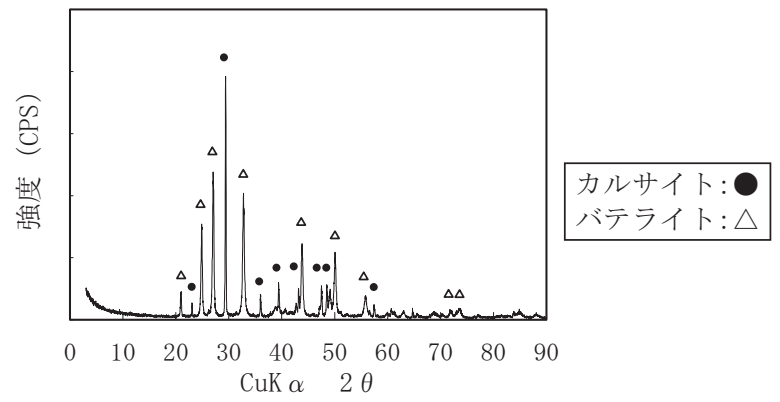

図 $2 \mathrm{CO}_{2}$ 吹込みにより析出した $\mathrm{CaCO}_{3}$ の X 線回折図形

\section{3 素材分離プロセス検討のまとめ}

\section{3.1 素材分離の手順}

廃コンクリート微粉末から、(1)骨材微細屑 (2)ケイ酸 (3)鉄分と アルミニウムを主成分とする不純物 (4) $\mathrm{CaCO}_{3}$ が分離できた。図 3 に その手順を示す。

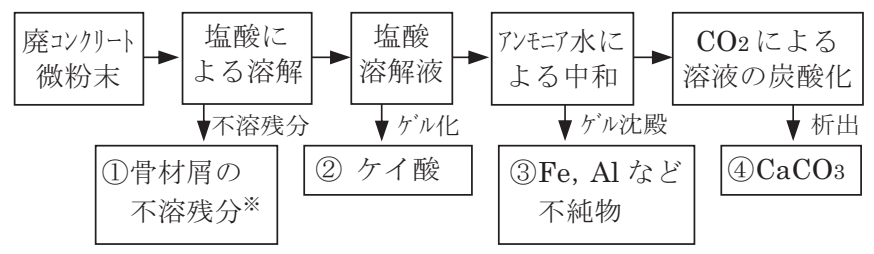

※ケイ酸を主成分とする石英、長石類、白雲母など

図 3 廃コンクリート微粉末の素材分離基礎プロセス

\section{3.2 マテリアルバランスの検討}

分離した各素材のマテリアルバランスを図 4 に示す。廃コンクリ 一下微粉末からは $35.9 \%$ の不溶残分が発生し、43.1\%の $\mathrm{CaCO}_{3}$ が析 出した。セメント微粉末は不溶残分が $2.5 \%$ とほとんどないことから、 CaCO3が $70.9 \%$ 得られた。 


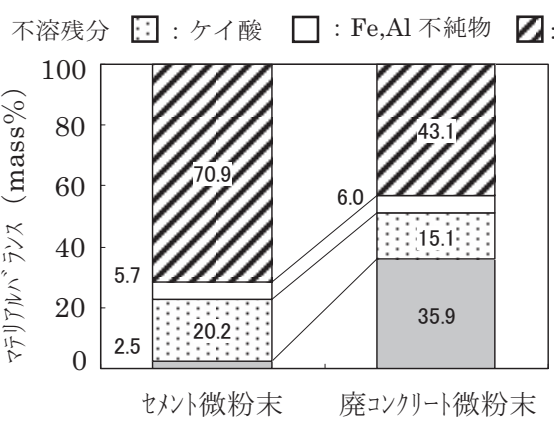

図 4 分離した素材のマテリアルバランス

\section{3. 分離プロセスの効率化検討試験}

2 章では、廃コンクリート微粉末から、各素材を分離する基本的な プロセスを構築する検討を行った。これらをさらに工業化するには、 素材分離をできるだけ短時間で行い、かつ、無駄な処理を抑える必 要がある。その観点から分離プロセスを見ると、廃コンクリート微 粉末を溶解し、不溶残分を除去した後に行うケイ酸のゲル化には相 当な時間がかかっており、処理プロセスとしては検討の余地がある。 また塩酸は、廃コンクリート微粉末を溶解させた後はアンモニア水 によって中和するため、可能な限り廃コンクリート微粉末を溶解さ せることが、無䭾な処理を抑えることとなる。ここでは、効率よい 処理が可能となる塩酸濃度と廃コンクリート微粉末の割合を把握す ることを目的とした試験を行った。試験手順は 2 章で示したプロセ スで行い、試験体も解体現場から発生した廃コンクリート塊の処理 において排出された、これまでの試験で用いたものと同じ廃コンク リート微粉末を用いた。

\section{1 試験方法}

\subsection{1 廃コンクリート微粉末の溶解}

廃コンクリート微粉末を溶解させる塩酸は、市販の塩酸を用いて 調整し、濃度を $2 \mathrm{~N} \sim 8 \mathrm{~N}$ の 4 種類を準備した。これらの塩酸 $50 \mathrm{~m} 1$ に、 廃コンクリート微粉末を $2.5 \sim 10.0 \mathrm{~g}$ に計量して投入した。組合せ数 は表 6 に示寸 16 通りである。

表 6 塩酸濃度と廃コンクリート微粉末の組合せ

\begin{tabular}{c|c|c|c|c}
\hline 塩酸濃度 & \multicolumn{4}{|c}{ 塩酸 $50 \mathrm{~m} 1$ に対する廃コンクリート微粉末の重量 $(\mathrm{g})$} \\
\hline $2 \mathrm{~N}$ & 2.5 & 5.0 & 7.5 & 10.0 \\
\hline $4 \mathrm{~N}$ & 2.5 & 5.0 & 7.5 & 10.0 \\
\hline $6 \mathrm{~N}$ & 2.5 & 5.0 & 7.5 & 10.0 \\
\hline $8 \mathrm{~N}$ & 2.5 & 5.0 & 7.5 & 10.0 \\
\hline
\end{tabular}

濃度の高い塩酸に、廃コンクリート微粉末を大量に投入すると、 大量の溶解熱が発生する。温度の上昇は、溶解反応に影響を与える 可能性が考えられたため、ここでは、溶液の温度が上昇しないよう にビーカーは水浴状態とした。樽谷の研究 ${ }^{6)}$ によると、溶液中のケ イ酸イオンのゲル化速度は、酸の濃度とケイ酸イオンの濃度に依存 寸るとされ、塩酸濃度が高いほど、溶解しているケイ酸イオンが多 いほど、ゲル加速度が速くなるとされている。今回の試験では、攪 拌中のゲル化をできるだけ少なくするために、攪拌時間を 5 分間と した。攪找後は、速やかに塩酸に溶け切らなかった不溶残分を吸引 ろ過し、溶液を分離した。

3.1.2 ケイ酸のゲル化
不溶残分を除去した塩酸溶解液は、蓋付きの試験管に入れて $40^{\circ} \mathrm{C}$ の温水中に入れて養生した。溶解液は目視で観察し、ゲル化の状態 と時間を記録し、溶解液全体がゲル化するまで観察を継続した。な お、ケイ酸のゲル化が終了したことを目視で厳密に判断するのは困 難ではあるが、次の処理段階としてゲル化したケイ酸と塩酸溶解液 に分離することが可能であれば良いことから、試験管を傾けるなど して全体が十分にゲル化した事が判断できる、最も簡便な目視観察 でゲル化時間を測定した。

溶解液全体がケイ酸のゲル化によって流動性を失った後に、ケイ 酸と溶解液を分離した。強固に全体がゲル化したケイ酸は試験管の 内側に付着しているため、ここでは、溶解液の $\mathrm{pH}$ を低い状態で維持 寸るために、 $2 \mathrm{~N}$ の塩酸を $50 \mathrm{~m} 1$ 準備し、試験管に数回に分けて入れな がら試験管をよく振り、十分に取り除いた。ビーカーに入れた溶解 液は、さらに攪挥してケイ酸を十分にほぐした後に、遠心分離機で ケイ酸と溶解液に分離した。

\subsection{3 塩酸溶解液の中和}

ケイ酸を分離した塩酸溶解液に、アンモニア水をゆっくりと滴下 して徐々に $\mathrm{pH}$ を昇させて中和液とした。この滴下の途中で発生す る沈殿物を観察した。発生した沈殿物は遠心分離機で分離した。

\subsection{4 溶液の炭酸化}

中和によって発生した沈殿物を除去したアンモニア中和液に炭酸 アンモニウム水溶液を滴下して、 $\mathrm{CaCO}_{3}$ を析出させた。

\section{2 試験結果}

\section{2.1 廃コンクリート微粉末の溶解}

廃コンクリート微粉末を塩酸に溶解し、不溶残分を除去した塩酸 溶解液の色は、塩酸濃度が高いほど、廃コンクリート微粉末の投入 量が多いほど、鮮やかな黄色が濃くなる傾向が見られた。表 7 には、 廃コンクリート微粉末投入後の各溶解液の $\mathrm{pH}$ を示す。塩酸濃度 $2 \mathrm{~N}$ では、廃コンクリート微粉末の投入量が多くなるほど $\mathrm{pH}$ が上昇する 傾向であり、塩酸濃度 $4 \mathrm{~N}$ でも $10.0 \mathrm{~g}$ 投入した際には $\mathrm{pH}$ の上昇が見 られた。これは、廃コンクリート微粉末が溶解する事によって中和 作用が発現し、低濃度の塩酸では $\mathrm{pH}$ が上昇したと考えられる。

表 7 廃コンクリート微粉末投入後の塩酸溶解液の $\mathrm{pH}$

\begin{tabular}{c|c|c|c|c}
\hline 塩酸 & \multicolumn{4}{|c}{ 塩酸 $50 \mathrm{~m} 1$ に対する廃コンクリート微粉末の重量 $(\mathrm{g})$} \\
\cline { 2 - 5 } 度 & 2.5 & 5.0 & 7.5 & 10.0 \\
\hline \hline $2 \mathrm{~N}$ & 0.05 & 0.15 & 0.44 & 2.56 \\
\hline $4 \mathrm{~N}$ & 0.00 以下 & 0.00 以下 & 0.00 以下 & 0.24 \\
\hline $6 \mathrm{~N}$ & 0.00 以下 & 0.00 以下 & 0.00 以下 & 0.00 以下 \\
\hline $8 \mathrm{~N}$ & 0.00 以下 & 0.00 以下 & 0.00 以下 & 分離不可能 \\
\hline
\end{tabular}

この他、不溶残分の分離に関しては以下の点について知見を得た。 (1)濃度 $2 \mathrm{~N}$ と $4 \mathrm{~N}$ の塩酸 $50 \mathrm{~m} 1$ に、廃コンクリート微粉末を $10.0 \mathrm{~g}$ 溶解 したものでは、不溶残分に粘りがあり、吸引ろ過にかなりの手間が かかった。これは、廃コンクリート微粉末が多いため、酸によって 十分に溶解できなかったためと考えられる。特に、濃度 $2 \mathrm{~N}$ の塩酸 $50 \mathrm{~m} 1$ に廃コンクリート微粉末を $10.0 \mathrm{~g}$ 溶解したものは、 $\mathrm{pH}$ が 2.56 まで上昇し、2 章で見られたように鉄分のゲル化が始まったため、不 溶残分がやや褐色となった。濃度 $6 \mathrm{~N}$ の塩酸 $50 \mathrm{ml}$ に廃コンクリート 微粉末を $10.0 \mathrm{~g}$ 溶解したものは、不溶残分が容易にろ過できた。 (2)濃度 $8 \mathrm{~N}$ の塩酸 $50 \mathrm{~m} 1$ に廃コンクリート微粉末を $10.0 \mathrm{~g}$ 溶解したも 
のでは、攪拌後の塩酸溶解液全体が流動化を失い、不溶残分と溶解 液の分離が十分に行えなかった。

\section{2.2 ケイ酸のゲル化}

図 5 には、各組合せにおけるケイ酸のゲル化時間を示す。ケイ酸 のゲル化は、試験管の内側にゲル状の物質が少しずつ付着し始め、 徐々に塩酸溶解液全体がゲル化する様子が観察された。また、塩酸 濃度 $2 \mathrm{~N}$ と $4 \mathrm{~N}$ 以上ではゲル化時間に大きな差が見られ、2 章での実験 で見られたように、塩酸濃度 $2 \mathrm{~N}$ ではゲル化時間が極端に長い。これ は、樽谷の研究 ${ }^{6)}$ に示されている塩酸濃度と溶解液中のケイ酸の分 ル化時間の傾向と一致している。処理効率を考慮すると、このゲル 化時間は短い方がよいが、極端に短い場合は不溶残分を分離する前 にゲル化が始まってしまう可能性があり、不溶残分と塩酸溶解液の 分離が困難となる。したがって、今後の工業的な展開を考え、現段 階において、ゲル化時間は 4 時間から 6 時間が適当と判断される。

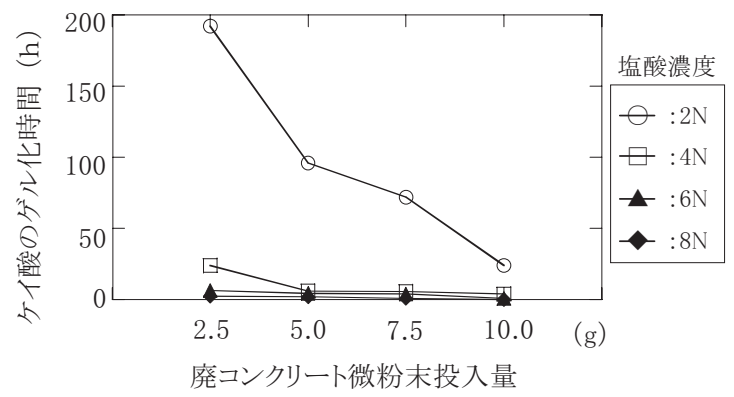

図 5 塩酸濃度とケイ酸のゲル化時間の関係

\section{2.3 塩酸溶解液の中和}

廃コンクリート微粉末を溶解させた塩酸溶解液は、全ての組合せ において $\mathrm{pH} 2$ ～ 3 あたりで褐色の水酸化鉄(III)ゲルが発生し、 $\mathrm{pH} 3$ 〜4から、白色の水酸化アルミニウムのゲル沈殿が発生した。

鉄やアルミニウムのゲルなどを除去した中和液はほぼ透明となっ たが、塩酸の濃度が高く、廃コンクリート微粉末の投入量が多いほ じ、薄く黄色がかっていた。この中和液を炭酸化する前にろ過して も、溶液の色は完全には無色透明にはならなかった。これは前出の 図 1 に示したように、 $\mathrm{Fe}^{2+}$ は $\mathrm{pH} 7$ あたりでは中和液中に存在している 可能性が高い。2 価の水酸化鉄 $\mathrm{Fe}(\mathrm{OH}) 2$ は緑白色であるが、水中で酸 化して褐色の 3 価の水酸化鉄 $\mathrm{Fe}(\mathrm{OH}) 3$ に変化することから、この溶 液の薄い黄色は、ごく僅かの $\mathrm{Fe}(\mathrm{OH}) 2$ が酸化して Fe $(\mathrm{OH}) 3$ に変化する ことによって見られる現象であると考えられる。

\section{2.4 溶液の炭酸化}

鉄とアルミニウムゲルを分離した溶解液を炭酸化することによっ て、 $\mathrm{CaCO}_{3}$ の白色結晶を析出させた。

ここで得られた $\mathrm{CaCO}_{3}$ は、試験体によって溶液中での沈殿速度や、 乾燥時の状態が異なっていたため、電子顕微鏡による形状観察と EPMA 分析を行った。測定に用いたのは、 $\mathrm{CaCO}_{3}$ の状態が明らかに異 なった、濃度 $2 \mathrm{~N}$ の塩酸 $50 \mathrm{~m} 1$ に廃コンクリート微粉末を $7.5 \mathrm{~g}$ 溶解し たものと、濃度 $8 \mathrm{~N}$ の塩酸 $50 \mathrm{~m} 1$ に廃コンクリート微粉末を $7.5 \mathrm{~g}$ 溶解 したものである。写真 2 にそれぞれの形状を示す。塩酸濃度 $2 \mathrm{~N} の$ $\mathrm{CaCO}_{3}$ は、立方体状の結晶が集まって $3 \mu \mathrm{m}$ 程度の球状となっている ことが分かる。塩酸濃度 $8 \mathrm{~N}$ の $\mathrm{CaCO}_{3}$ も、立方体状の結晶が集まって 球状となっているが、一つの大きさが $30 \mu \mathrm{m}$ 程度もあり、塩酸濃度 $2 \mathrm{~N}$ より 10 倍ほど大きい

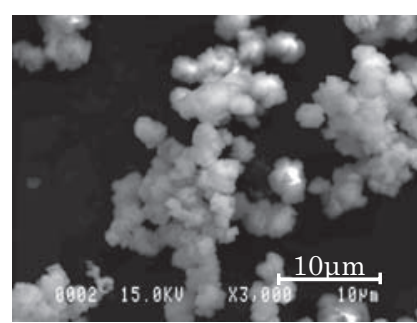

(1) 濃度 $2 \mathrm{~N}$ の塩酸 $50 \mathrm{ml}$ 廃コンクリート微粉末 $7.5 \mathrm{~g}$

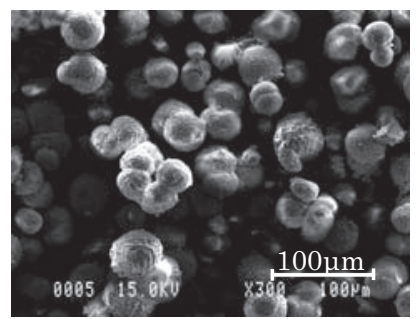

(2) 濃度 $8 \mathrm{~N}$ の塩酸 $50 \mathrm{ml}$ 廃コンクリート微粉末 $7.5 \mathrm{~g}$
写真 2 析出した炭酸カルシウムの形状

この $\mathrm{CaCO}_{3}$ の EPMA による分析結果を表 8 に示す。マグネシウムと リンが多少含まれるが、純度の高い $\mathrm{CaCO}_{3}$ が得られた。なお、分析 結果に現れている $\mathrm{Cu}$ は、試験体を付着させている試料台を検出した 可能性が高い。

表 8 析出した炭酸カルシウムの内訳 (mass\%)

\begin{tabular}{c|c|c|c|c}
\hline \multirow{2}{*}{ 試料の種類 } & \multicolumn{4}{|c}{ 分析結果 } \\
\cline { 2 - 5 } & $\mathrm{Mg} 0$ & $\mathrm{P} 205$ & $\mathrm{Cu} 0$ & $\mathrm{Ca} 0$ \\
\hline \hline $\begin{array}{c}\text { 濃度 } 2 \mathrm{~N} \text { の塩酸 } 50 \mathrm{~m} 1 \\
\text { 廃コンクリート微粉末 } 7.5 \mathrm{~g}\end{array}$ & 0.31 & 1.72 & - & 98.0 \\
\hline $\begin{array}{c}\text { 濃度 } 8 \mathrm{~N} \text { の塩酸 } 50 \mathrm{~m} 1 \\
\text { 廃コンクリート微粉末 } 7.5 \mathrm{~g}\end{array}$ & 0.89 & 1.40 & 2.44 & 95.3 \\
\hline
\end{tabular}

今回得られた $\mathrm{CaCO}_{3}$ の X線回折の結果では、表 9 に示すように安 定相であるカルサイトと、太線で囲んだ組合せにおいてはカルサイ トとバテライトが検出された。すなわち、中和に使用したアンモニ ア水が多いほどバテライトになりやすい傾向となっている。特に、 塩酸濃度 $8 \mathrm{~N}$ に廃コンクリート微粉末 $2.5 \mathrm{~g}$ と $5.0 \mathrm{~g}$ 投入した組合せで は、ほとんどがバテライトとなった。

表 $9 \mathrm{CaCO}_{3}$ のX線回折分析結果 (カルサイトとバテライトの割合)

\begin{tabular}{|c|c|c|c|c|}
\hline \multirow{2}{*}{$\begin{array}{l}\text { 塩酸 } \\
\text { 濃度 }\end{array}$} & \multicolumn{4}{|c|}{ 塩酸 50m1 に対する廃コンクリート微粉末の重量（g） } \\
\hline & 2.5 & 5.0 & 7.5 & 10.0 \\
\hline $2 \mathrm{~N}$ & $\begin{array}{l}\text { カル少イト: } 88 \\
\text { バテライト: } 12\end{array}$ & $\begin{array}{c}\text { カル开イト：100 } \\
\text { バテラライト:0 }\end{array}$ & $\begin{array}{c}\text { カルササ卜卜 : } 100 \\
\text { バテライト }\end{array}$ & $\begin{array}{c}\text { カル开仆：100 } \\
\text { バテライト }\end{array}$ \\
\hline $4 \mathrm{~N}$ & $\begin{array}{l}\text { カルサイト : } 40 \\
\text { バテライト: } 60\end{array}$ & $\begin{array}{c}\text { カルササト : } 100 \\
\text { バテライト:0 }\end{array}$ & $\begin{array}{c}\text { カルサイト : } 100 \\
\text { バテライト:0 }\end{array}$ & $\begin{array}{c}\text { カル仆：100 } \\
\text { バテライト：0 }\end{array}$ \\
\hline $6 \mathrm{~N}$ & $\begin{array}{l}\text { カルサイト : } 85 \\
\text { バテライト: } 15\end{array}$ & $\begin{array}{l}\text { カルサトト : } 42 \\
\text { バテライト: } 58\end{array}$ & $\begin{array}{l}\text { カルサイト : } 72 \\
\text { バテライト: } 28\end{array}$ & $\begin{array}{c}\text { カル少イト : } 100 \\
\text { バテライト: }\end{array}$ \\
\hline $8 \mathrm{~N}$ & $\begin{array}{l}\text { カルササト : } 16 \\
\text { バテライト:84 }\end{array}$ & $\begin{array}{l}\text { カルサイト : } 4 \\
\text { バテライト:96 }\end{array}$ & $\begin{array}{l}\text { カルサイト : } 96 \\
\text { バテラライ: }\end{array}$ & - \\
\hline
\end{tabular}

\section{3 マテリアルバランスの検討}

図 6 には、分離できた各素材、中和に用いたアンモニア水および $\mathrm{CaCO}_{3}$ を分離した後の塩化アンモニウム水溶液のマテリアルバラン スについて示す。それぞれについて検討した内容を以下に示す。

\section{(1) 不溶残分}

全ての塩酸の濃度において、廃コンクリート微粉末の投入量が多 いほど、不溶残分の割合が多くなる傾向である。このうち塩酸濃度 $6 \mathrm{~N}$ は、他の濃度と比較して不溶残分の割合が少ない傾向であり、最 も良く廃コンクリート微粉末を溶解させたと考えられる。塩酸濃度 $8 \mathrm{~N}$ に廃コンクリート微粉末を $7.5 \mathrm{~g}$ 溶解した場合では、ケイ酸のゲル 化が速やかであり、不溶残分にケイ酸が含まれている可能性がある。 (2) ケイ酸

塩酸濃度 $2 \mathrm{~N}$ は、他の塩酸濃度と比較すると、ケイ酸の割合が大き 
い。塩酸濃度 $8 \mathrm{~N}$ が他の濃度より少ないのは、攪拌時にケイ酸が不溶 残分に混入した影響と考えられる。塩酸濃度 $2 \mathrm{~N}$ に廃コンクリート微 粉末を $10.0 \mathrm{~g}$ 溶解した場合、廃コンクリート微粉末が十分に溶け切 らないために、ケイ酸の割合が極端に低下している。

（3） Fe、A1 ゲルなど不純物

廃コンクリート微粉末の投入量が大きいほど、Fe、A1 ゲルなどの 不純物の割合は低下寸る傾向である。

(4) $\mathrm{CaCO}_{3}$

全ての塩酸溶解液において、廃コンクリート微粉末の投入量が多 いほど、 $\mathrm{CaCO}_{3}$ の割合は低下寸る傾向である。このうち、塩酸濃度 $6 \mathrm{~N}$ は、比較的他の濃度よりも割合が高い傾向が見られる。

（5）中和に使用したアンモニア水

塩酸の濃度が同じ場合は、廃コンクリートの投入量が多いほど、 中和に用いたアンモニア水の量は少なくなる。これは、廃コンクリ 一トを溶解したことによって、塩酸の中和効果が発揮されたことと、 中和前の溶解液の量が少なくなっているためである。同じ廃コンク リート微粉末の投入量で比較すると、塩酸濃度が高くなるにしたが って、中和に必要なアンモニア水の量は多くなる傾向である。

（6）炭酸化後の塩化アンモニウム水溶液

$\mathrm{CaCO}_{3}$ を除去した後の無色透明の溶液は、塩化アンモニウム水溶液 である。同じ塩酸濃度では、廃コンクリート微粉末の量が多いほど、 塩化アンモニウム水溶液の量は減少寸る傾向である。これは、分離 素材の量が多いほど、分離の際に溶液が減少寸ることと、中和に用 いたアンモニア水が少ないためである。

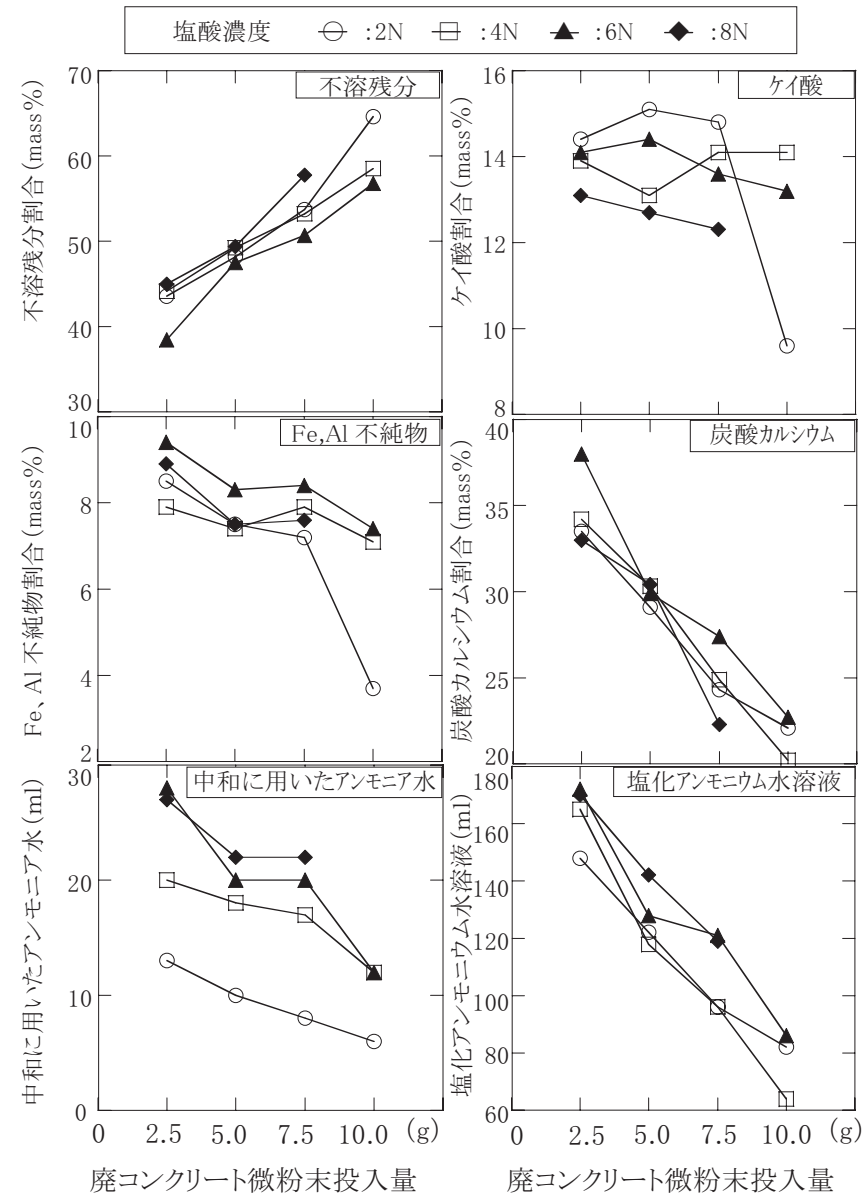

図 6 分離素材のマテリアルバランスと溶液の量

\section{4 処理プロセスの評価}

廃コンクリート微粉末処理のプロセスについて、反応効率や作業 時間および塩酸濃度と廃コンクリート微粉末の投入量のバランスを まとめると表 10 の様になる。以下に内容をまとめた。

表 10 処理プロセスの評価

\begin{tabular}{|c|c|c|c|c|c|}
\hline \multirow{2}{*}{$\begin{array}{l}\text { 塩酸 } \\
\text { 濃度 }\end{array}$} & \multirow{2}{*}{ 項目 } & \multicolumn{4}{|c|}{ 廃コンクリート微粉末重量 $(\mathrm{g})$} \\
\hline & & 2.5 & 5.0 & 7.5 & 10.0 \\
\hline \multirow{4}{*}{$2 \mathrm{~N}$} & 不溶残分の分離 & $\bigcirc$ & $\bigcirc$ & 0 & $x$ \\
\hline & ケイ酸のゲル化時間 & 8 日 & 4 日 & 3 日 & $24: 00$ \\
\hline & 中和に用いたアンモニア水量 (m1) & 13 & 10 & 8 & 6 \\
\hline & 塩化アソモニウム水溶液 $(\mathrm{m} 1)$ & 148 & 122 & 96 & 82 \\
\hline \multirow{4}{*}{$4 \mathrm{~N}$} & 不溶残分の分離 & $\bigcirc$ & 0 & 0 & $\triangle$ \\
\hline & ケイ酸のゲル化時間 & $24: 00$ & $6: 00$ & $5: 30$ & $4: 00$ \\
\hline & 中和に用いたアソモニア水量 $(\mathrm{m} 1)$ & 20 & 18 & 17 & 12 \\
\hline & 塩化アソモニウム水溶液 (m1) & 165 & 128 & 96 & 64 \\
\hline \multirow{4}{*}{$6 \mathrm{~N}$} & 不溶残分の分離 & 0 & 0 & 0 & $\bigcirc$ \\
\hline & ケイ酸のゲル化時間 & $6: 30$ & $4: 30$ & $4: 00$ & 0.45 \\
\hline & 中和に用いたアソモニア水量 $(\mathrm{m} 1)$ & 28 & 20 & 20 & 12 \\
\hline & 塩化アソモニウム水溶液 (m1) & 172 & 128 & 121 & 86 \\
\hline \multirow{4}{*}{$8 \mathrm{~N}$} & 不溶残分の分離 & $\bigcirc$ & $\bigcirc$ & 0 & $\times$ \\
\hline & ケイ酸のゲル化時間 & $2: 25$ & $2: 00$ & $1: 00$ & $0: 10$ \\
\hline & 中和に用いたアンモニア水量 (m1) & 27 & 22 & 22 & - \\
\hline & 塩化アソモニウム水溶液 $(\mathrm{m} 1)$ & 170 & 142 & 119 & - \\
\hline
\end{tabular}

注）不溶残分の分離 $\bigcirc$ : 可能 $\triangle$ : 可能だが手間がかかる $\times$ : 不可能

（1）塩酸濃度 $2 \mathrm{~N}$ の場合、ケイ酸のゲル化に時間がかかる。また、 投入寸る廃コンクリート微粉末を塩酸 $50 \mathrm{~m} 1$ に対して $10.0 \mathrm{~g}$ と寸ると、 十分な溶解が進まず、塩酸溶解液と不溶残分の分離に手間がかかる ようになる。また、液性が $\mathrm{pH} 2$ 以上に上昇寸るため、塩酸溶解液中 の鉄分がゲル化する。

(2) 濃度 $4 \mathrm{~N}$ の塩酸 $50 \mathrm{~m} 1$ に対して廃コンクリート微粉末 $10.0 \mathrm{~g}$ 溶解 した場合は不溶残分が分離しにくくなる以外は、比較的扱いやすい。 作業効率、マテリアルバランスおよび溶液の量より、濃度 $4 \mathrm{~N}$ の塩酸 $50 \mathrm{~m} 1$ に対して廃コンクリート微粉末は $5.0 \mathrm{~g} \sim 7.5 \mathrm{~g}$ が良いと考えら れる。

(3) 濃度 $6 \mathrm{~N}$ の塩酸 $50 \mathrm{~m} 1$ では、全ての廃コンクリート微粉末の投入 量に対して十分に溶解させるが、廃コンクリート微粉末 $2.5 \mathrm{~g}$ では投 入量が少ないため、中和に必要なアンモニア水の量が多くなる。ま た、廃コンクリート微粉末 $10.0 \mathrm{~g}$ ではケイ酸のゲル化が速すぎるた め、廃コンクリート微粉末は $5.0 \mathrm{~g} \sim 7.5 \mathrm{~g}$ が良いと考えられる。

（4）塩酸濃度 $8 \mathrm{~N}$ の場合、ケイ酸のゲル時間が速過ぎて溶液との分 離が困難である。また、中和に用いるアンモニア水の量が多い。

以上より、塩酸濃度と廃コンクリート微粉末の組合わせは、表中 で囲った範囲が、不溶残分と塩酸溶解液との分離作業をスムーズに 行い、ケイ酸をゲル化させて次の工程に移る手順が無理なく行うこ とができ、かつ、中和に用いるアンモニア水の量が比較的少ないと 言った観点で、バランスが良いと考えられる。

\section{4. 塩酸溶解時の攪拌時間検討試験}

3 章で行った試験では、塩酸濃度と投入する廃コンクリート微粉末 の量によって、ケイ酸のゲル化が極端に速くなることを考慮して、 
攪拌時間を短く 5 分間に設定した。ところが、図 7 に示すように、 濃度 $2 \mathrm{~N}$ の塩酸 $50 \mathrm{~m} 1$ に廃コンクリート微粉末 $2.5 \mathrm{~g}$ 投入し、約 18 時 間攪挥した試験のマテリアルバランスと、3 章でバランスの良いとし た組合せのマテリアルバランスを比較すると、後者は不溶残分が多 く、炭酸カルシウムの割合が小さい。工業的な展開を考慮するなら ば、処理後のマテリアルバランスは、不溶残分が少なく、炭酸カル シウムが多いほうが望ましい。しかし、濃度 $2 \mathrm{~N}$ の塩酸 $50 \mathrm{~m} 1$ に廃コ ンクリート微粉末 $2.5 \mathrm{~g}$ 投入する場合は、2 章で試験したように溶解 時間とケイ酸のゲル化時間には全部で数日間かかる事になり、工業 的な処理を考慮すると効率は極めて悪い。したがってここでは、処 理プロセスの評価においてバランスが良いと判断された塩酸濃度と 廃コンクリート微粉末との組合せにおいて、攪拌時間を変えること によって、マテリアルバランスがどの様に変化するかの検討を行っ た。

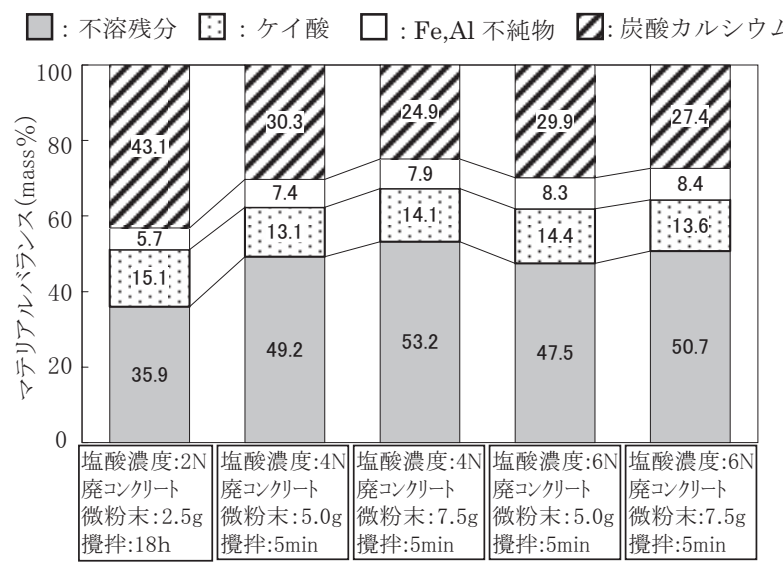

注）廃コンクリート微粉末は、塩酸 $50 \mathrm{ml}$ に対する重量

図 7 マテリアルバランスの比較

\section{1 試験方法}

用いた試験体は、これまでの試験で使用してものと同じ廃コンク リート微粉末である。表 11 に示すように、濃度 $4 \mathrm{~N}$ と $6 \mathrm{~N}$ の塩酸 $50 \mathrm{ml}$ に、廃コンクリート微粉末 $5.0 \mathrm{~g}$ と $7.5 \mathrm{~g}$ をそれぞれ投入し、攪挥時 間を 30 分から 180 分（3 時間）まで変えた 12 種類の試験を行った。

表 11 塩酸溶解における攪汼時間の試験条件

\begin{tabular}{|c|c|c|c|c|}
\hline \multicolumn{2}{|r|}{ 組合せ } & \multicolumn{3}{|c|}{ 攪汼時間 $(\mathrm{min})$} \\
\hline \multirow{2}{*}{$\begin{array}{l}\text { 濃度 } 4 \mathrm{~N} \text { の } \\
\text { 塩酸 } 50 \mathrm{~m} 1\end{array}$} & 廃コンクリート微粉末 $5.0 \mathrm{~g}$ & 30 & 60 & 180 \\
\hline & 廃コンクリート微粉末 $7.5 \mathrm{~g}$ & 30 & 60 & 180 \\
\hline \multirow{2}{*}{$\begin{array}{c}\text { 濃度 } 6 \mathrm{~N} \text { の } \\
\text { 塩酸 } 50 \mathrm{~m} 1\end{array}$} & 廃コンクリート微粉末 $5.0 \mathrm{~g}$ & 30 & 60 & 180 \\
\hline & 廃コンクリート微粉末 $7.5 \mathrm{~g}$ & 30 & 60 & 180 \\
\hline
\end{tabular}

試験手順はこれまでと同様に、以下の手順で行った。

(1)塩酸に廃コンクリート微粉末を少しずつ投入し、設定した時間ま で攪找し、速やかにろ過して不溶残分と塩酸溶解液に分離した。

(2)塩酸溶解液を蓋付きの試験管に移してから $40^{\circ} \mathrm{C}$ で養生し、ケイ酸 をゲル化させた。ゲル化したケイ酸は、濃度 $2 \mathrm{~N}$ の塩酸 $50 \mathrm{~m} 1$ を加え ながら良く振り、試験管内に付着したケイ酸を全てビーカーに移し た。ビーカー内で攪拌の後、遠心分離によりケイ酸と溶液に分離し た。

(3)分離した塩酸溶解液を、アンモニア水で中和させ、その過程で発
生する鉄とアルミニウムゲルを遠心分離により、アンモニア中和液 と分離した。

(5)得られたアンモニア中和液に、炭酸アンモニウム水溶液を滴下寸 る事により、 $\mathrm{CaCO}_{3}$ を析出させた。

\section{2 試験結果}

得られた各素材のマテリアルバランスを図 8 に示す。以下に得ら れた結果をまとめた。

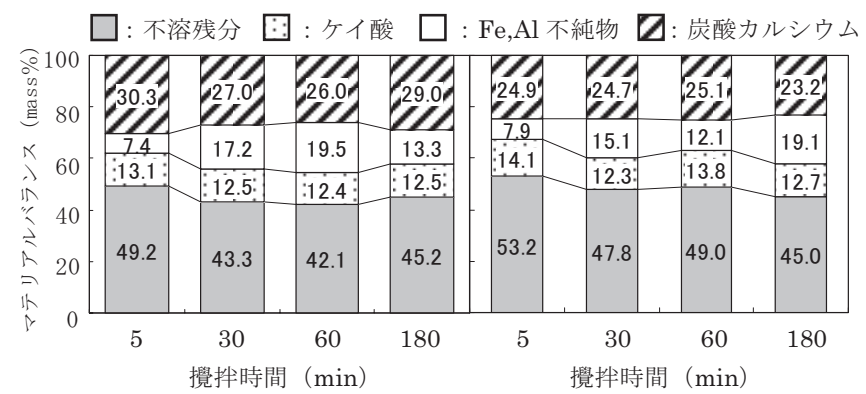

(1)濃度 $4 \mathrm{~N}$ の塩酸 $50 \mathrm{ml}$

(2)濃度 $4 \mathrm{~N}$ の塩酸 $50 \mathrm{ml}$ 廃コンクリート微粉末 $5.0 \mathrm{~g}$ 廃コンクリート微粉末 $7.5 \mathrm{~g}$

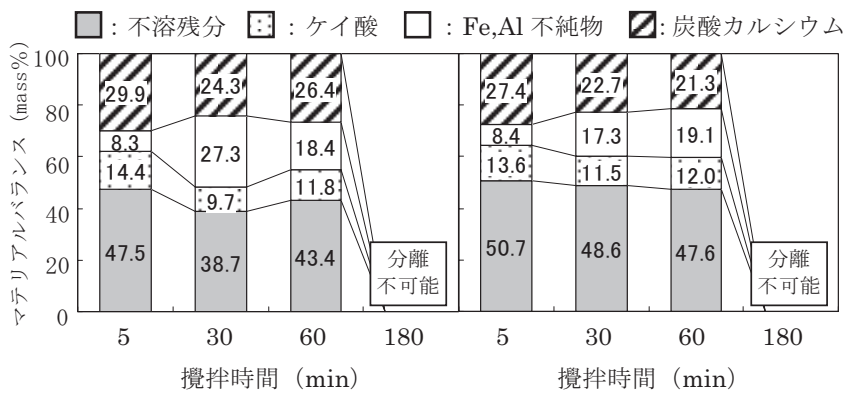

(3)濃度 $6 \mathrm{~N}$ の塩酸 $50 \mathrm{ml}$

(4)濃度 $6 \mathrm{~N}$ の塩酸 $50 \mathrm{ml}$ 廃コンクリート微粉末 $5.0 \mathrm{~g}$ 廃コンクリート微粉末 $7.5 \mathrm{~g}$

※攪拌時間 180 分はケイ酸のゲル化により分離不可能

図 8 攪拌時間によるマテリアルバランスの比

(1) 不溶残分は、全ての組合せにおいて攪拌時間を 30 分以上として も、攪拌時間 5 分間と比較して、わずかしか減少しなかった。 (2)个イ酸は、全ての組合せにおいて不溶残分と増減の傾向が似てい るが、攪汼時間による割合の変化は、他の分離素材と比較するとあ まり大きくない。

(3) Fe、A1 ゲルなどの不純物は、攪拌時間による割合の変化が大きい。 濃度 $4 \mathrm{~N}$ の塩酸 $50 \mathrm{~m} 1$ に、廃コンクリート微粉末 $5.0 \mathrm{~g}$ の組合せでは、 拡販時間 60 分で最も多くなり、その後は減少している。濃度 $6 \mathrm{~N}$ の 塩酸 $50 \mathrm{~m} 1$ に廃コンクリート微粉末 $7.5 \mathrm{~g}$ の組合せでも、30 分が最大 となっている。したがって、この範囲においては不溶残分に含まれ る FeやA1 が塩酸に溶解していると考えられる。

(4) $\mathrm{CaCO}_{3}$ は、 $\mathrm{Fe} 、 \mathrm{~A} 1$ ゲルなどの不純物が増加する場合は減少し、 $\mathrm{Fe}$ 、 A1 ゲルなどの不純物が減少する場合は増加する傾向である。これは、 $\mathrm{CaCO}_{3}$ は手順として、Fe、A1 ゲルなどの不純物を除去した後の溶液 を使用することが影響していると考えられる。すなわち、攪找によ って不溶残分に含まれているカルシウムも塩酸に溶解しているが、 $\mathrm{Fe}$ 、A1 のゲルが多く発生する場合は、カルシウムが溶解している塩 酸溶液を取り込んでしまうため、最終的に析出する $\mathrm{CaCO}_{3}$ が少なく 
なっているためと考えられる。

以上より、試験に用いた組合せでは、攪拌時間を 5 分より長くす ることによって、不溶残分の割合は若干減らすことはできたが、大 幅に改善することはできなかった。不溶残分が減少した分は、Fe、 $\mathrm{A} 1$ 不純物が増加し、 $\mathrm{CaCO} 3$ は減少寸る傾向であった。Fe、A1 不純物 は現在のところ、分離しても利用方法が見出せないため、割合を増 加させる必要はなく、不溶残分として分離する方が良い。したがっ て、攪拌時間の検討を行った組合せでは、 5 分の攪拌時間で十分であ るといえる。

\section{5. 結論}

廃コンクリート微粉末の素材分離に関して、以下の結論を得た。

（1）廃コンクリート微粉末に含まれる素材を、不溶残分、ケイ酸、 鉄とアルミニウムの不純物、および $\mathrm{CaCO} 3$ に分離するプロセスを作 成した。

（2）分離プロセスの効率や、使用する試薬と最後に残る溶液の量を 比較することによって、塩酸濃度と投入する廃コンクリート微粉末 のバランスの良い組合せを以下の通りに見出した。

(1)濃度 $4 \mathrm{~N}$ の塩酸 $50 \mathrm{~m} 1$ に対して廃コンクリート微粉末 $5.0 \mathrm{~g} \sim 7.5 \mathrm{~g}$ (2)濃度 $6 \mathrm{~N}$ の塩酸 $50 \mathrm{~m} 1$ に対して廃コンクリート微粉末 $5.0 \mathrm{~g} \sim 7.5 \mathrm{~g}$

(3) バランスが良いとした塩酸濃度と廃コンクリート微粉末の組合 せにおいては、攪找時間は 5 分間で十分であることが分かった。

なお、今回は素材分離のプロセスを作成するために、廃コンクリ 一ト微粉末の溶解には純粋な塩酸を用いている。今後は、省エネル ギーの観点から、工業活動によって排出・処理されている廃酸を用 いた処理を計画している。

\section{謝辞}

本研究は、平成 19 年度東京工業大学応用セラミックス研究所共同 利用研究「廃コンクリート微粉末の素材リサイクルに関する研究」 によりました。また、国土交通省住宅·建築関連先導技術開発助成事 業費補助金「高品質再生細骨材 H の製造をコアとしたコンクリート リサイクル技術の開発」の一部を利用しました。

\section{参考文献}

1)内山伸, 黒田泰弘 : 加熱すりもみ処理したコンクリート微粉末に関する研究 （その 1 微粉末の製造条件および基本特性），第 47 回日本学術会議材料研 究連合講演会, pp. 261-262, 2003

2) 勝山泰郎:廃コンクリート微粉末からの炭酸カルシウム生成による二酸化炭 素排出削減技術の開発，東京大学大学院新領域創成科学研究科修士論文, 2004

3)山田興一ほか:アルカリ土類金属を利用した新規 $\mathrm{CO}_{2}$ 炭酸塩固定化システム の開発, RITE 化学研究グループ, 2006

4) 江藤良弘，中原敏次：現場で役立つ無機排水処理技術，株式会社工業調査会， 2005

5)安江任ほか：バテライトの合成と形態制御, 石膏と石灰, No. 247, pp. 63-72, 1993

6) 樽谷俊和 : 水中におけるケイ酸に関する研究（第 2 報）ケイ酸コロイドの生成 と平衡値について, 日本化学雑誌 77, pp. 1721-1727, 1956

（2008年 3 月 10 日原稿受理， 2008年 7 月25日採用決定） 